\title{
Biologists out of Africa over rhino dispute
}

Washington. Two US conservation biologists have been forced to abandon their research into the effects of removing the horns of rhinos in Namibia, after government officials took exception to their preliminary conclusions pointing out the dangers of such a procedure.

Joel Berger and Carol Cunningham of the University of Nevada at Reno left the country only days after an article that they had written appeared in the 4 March issue of the journal Science. The article argues that dehorning black rhinos may leave the animals unable to protect their young from predators.

Berger and Cunningham - a married couple who have carried out extensive studies of the ecology and conservation of bison - say they had to leave Namibia when the government refused to renew their authorization to conduct research, three years into a four-year programme.

But in a statement issued on behalf of Namibia's environment ministry, Malan Lindeque, chief ecologist the research was conducted, denies that the pair had been expelled, although he concedes that Namibia was dissatisfied with their work

In Namibia, dehorning is carried out by government conservation agencies in order to make dehorned animals unattractive to poachers. The government keeps the valuable rhino horn, which it hopes to sell abroad if a current ban on such trade is lifted.

Berger and Cunningham started looking at the effects of this policy in 1991 with a $\$ 130,000$ grant from the National Science Foundation, as well as support from various other bodies in the US and Sweden. Their early results indicated that the calves of dehorned rhino were likely to die if predaat the Etosha National Park where much of

tors, such as hyenas, were present. The Science article argues that "dehorning appears imprudent unless dangerous carnivores are removed".

Berger says Namibian officials were kept informed of the work through progress reports, including one in July 1993 that contained key language "almost identical to the

\section{IMAGE UNAVAILABLE FOR COPYRIGHT REASONS}

Berger (right) claims that anti-poaching procedures leave young rhinos defenceless.

Science paper". But he says they were upset by an article published in the journal Conservation Biology last December, and that "the Science paper was the straw that broke the camel's back".

Berger and Cunningham returned to Namibia from a period in the United States on 1 March, and gave officials proofs of the Science article. They were asked to submit a new research proposal for the coming year, which they did.

But they were told that the new proposal would need to be reconsidered from scratch, and that, according to Berger, "we were free to stay in Namibia as tourists but not to continue research". Given growing hostility to their presence from some biologists and non-government organizations, the pair returned to the United States on 20 March.

\section{US and China resume talks on cooperation}

Washington. Chinese and US science delegations met in Washington last week for the first time since their previous biannual meetings were suspended in the wake of the 1989 Tian'anmen square massacre.

The meeting of the Joint Commission on Scientific and Technological Cooperation discussed cooperative research in the areas of environmental technology, energy efficiency, drug development and advanced materials. An agreement on joint research in marine and fisheries science and technology was renewed and an accord on clean coal research signed.

An official of the White House Office of Science and Technology Policy said that the four areas identified for future joint projects are "illustrative, not com- prehensive", and are meant to alert government agencies to opportunities for future cooperation. "It's really up to the technical agencies and the private sector to pursue these opportunities as they see fit."

Twenty-seven protocols are already in place, which typically allow for cooperation between a single Chinese science agency and its US counterpart in a specific area of mutual interest. The meeting, co-chaired by John Gibbons, the US presidential science adviser, and the Chinese science minister, Song Jian, was one of a number of activities planned to lead up to the decision to be made in June by the US President, Bill Clinton, on whether to renew China's 'most-favoured nation' trading status. Tony Reichhardt
Berger describes the Namibian response to the research findings as "hysterical" and claims that one official said the underlying reason was the money at stake in conducting the dehorning programme and in selling the horns. But Lindeque says that Berger and Cunningham have "grossly overreacted" and displayed "hypersensitivity to criticism" in leaving the country. "We have remained willing to resolve [the situation] in $\mathrm{Na}-$ mibia," he says.

Lindique adds that the country's hospitality to foreign researchers should be reciprocated by a regard for local customs and concerns. "Our country and our way of managing it is more than just another study area or project for a foreign scientist, to be coldly dissected in foreign scientific journals," he says.

$\mathrm{He}$ argues that the two re-

searchers showed no sensitivity to issues of concern to Namibians. "They chose to communicate with us by way of American scientific journals, claiming that pressure from grant sources to publish quickly superseded the courtesy of obtaining comment from their hosts." Berger says that he met with Namibian officials last summer to discuss the preliminary results, and also submitted them seventeenth months ago for publication in the Namibian journal Madoqua.

John Robinson, vice-president of the Wildlife Conservation Society, based in New York, which helped to support Berger and Cunningham, claims that Namibia's actions represent "nothing but the muzzling of scientific enquiry". He says that the incident sets a dangerous precedent at a time when biologists are bringing science to bear on conservation policy, a field traditionally driven by little more than the whims of individuals. "This is clearly a case where science and conservation policy have got mixed up," says Robinson.

"A government can't say that it is taking a scientific approach to resource management if it takes sanctions against credible scientists whose research results conflict with government policy," says Peter Brussard, president of the US-based Society for Conservation Biology.

Officials from US Agency for International Development and the US embassy in Windhoek have raised the incident with Namibian environment minister Hanno Rumpf, and say he is adamant that the pair will not be authorized to continue their research. Berger and Cunningham now plan to finish writing up their Namibian work and move on to a new topic. "We want something that isn't so controversial," says Berger.

Colin Macilwain 